\title{
Efek Suplemen Bawang Putih terhadap Kadar Kolesterol dan Trigliserida pada Tikus Wistar yang Diberi Diet Tinggi Minyak Sawit
}

Mulfa Satria Asnel ${ }^{1}$, Husnil Kadri ${ }^{2}$, Dessy Arisanty ${ }^{2}$

\begin{abstract}
Abstrak
Minyak kelapa sawit banyak mengandung asam lemak jenuh yang diduga dapat menyebabkan kolesterol dan trigliserida meningkat. Tujuan penelitian ini adalah mengetahui efek suplemen bawang putih terhadap kadar kolesterol dan trigliserida tikus galur wistar yang diberi diet tinggi minyak sawit. Ini merupakan penelitian eksperimental dengan randomized post test control group design. Subjek penelitian adalah 15 ekor tikus Wistar jantan yang dibagi menjadi tiga kelompok, yaitu kelompok diet standar ad libitum, kelompok diet tinggi minyak sawit dan kelompok perlakuan (diet tinggi minyak sawit+suplemen bawang putih). Masing-masing kelompok terdiri dari lima ekor tikus. Pemberian minyak sawit dengan kadar $3 \mathrm{ml} / 15$ gram pakan standar diberikan kepada kelompok diet tinggi minyak sawit dan kelompok perlakuan selama empat minggu. Pemberian suplemen bawang putih (dosis 3,6 mg/200 mgBB tikus) diberikan kepada kelompok perlakuan selama empat minggu. Kadar kolesterol pada kelompok diet tinggi minyak sawit adalah $109 \pm$ 2,76 mg/dl dan pada kelompok perlakuan adalah $107 \pm 3,09 \mathrm{mg} / \mathrm{dl}$. Kadar trigliserida pada kelompok diet tinggi minyak sawit adalah $84 \pm 4,27 \mathrm{mg} / \mathrm{dl}$, pada kelompok perlakuan adalah $83 \pm 6,02 \mathrm{mg} / \mathrm{dl}$. Tidak terdapat perbedaan yang bermakna kadar kolesterol dan trigliserida antara kelompok diet tinggi minyak sawit dengan kelompok perlakuan. Pada kelompok diet standar ad libitum dengan kelompok diet tinggi minyak sawit maupun antara kelompok diet standar ad libitum dengan kelompok perlakuan terdapat perbedaan yang bermakna pada kadar kolesterol dan trigliserida.
\end{abstract}

Kata kunci: minyak sawit, suplemen bawang putih, kolesterol, trigliserida

\begin{abstract}
Palm oil contains a lot of saturated fatty acids and it is supposed to cause increased cholesterol and triglyceride levels. The objective of this study was to determine the effect of garlic supplements on cholesterol levels and triglyceride at wistar strain rats which were fed in high diet palm oil. This study is a randomized experimental study with post-test control group design. The subjects were 15 male wistar rats were divided into three groups, standard ad libitum diet group, high diet palm oil group and the treatment group (high diet palm oil+ garlic supplement). Each group consists of five rats. Provision of palm oil with high levels of standard $3 \mathrm{ml} / 15 \mathrm{grams}$ of feeding given to the high diet palm oil group and the treatment group during the four weeks. Garlic supplement (dose $3.6 \mathrm{mg} / 200 \mathrm{mgweight}$ rat) was given to the treatment group for four weeks. Cholesterol levels in the high diet palm oil group was $109 \pm 2,76 \mathrm{mg} / \mathrm{dl}$ in the treatment group was $107 \pm 3,09 \mathrm{mg} / \mathrm{dl}$. The levels of triglycerides in the high diet palm oil group was $84 \pm 4,27$ $\mathrm{mg} / \mathrm{dl}$ and in the treatment group was $83 \pm 6,02 \mathrm{mg} / \mathrm{dl}$. There was no significant difference the levels of cholesterol and triglycerides between the high diet palm oil group with the treatment group. Between the standard ad libitum diet group with the high diet palm oil group and between the standard ad libitum diet group with the treatment group show there were significant differences in the levels of cholesterol and triglycerides.
\end{abstract}

Keywords: palm oil, garlic supplement, cholesterol, triglyceride

Affiliasi penulis : 1. Pendidikan Dokter FK UNAND (Fakultas Kedokteran Universitas Andalas), 2. Bagian Biokimia FK UNAND
Korespondensi : Mulfa Satria Asnel, E-mail :

mulfa_satria@yahoo.com, Telp: 085263054001 


\section{PENDAHULUAN}

Dislipidemia meliputi dua kondisi yaitu, kolesterol tinggi dan trigliserida tinggi. Keduanya memicu aterosklerosis dan mempertinggi risiko penyakit kardiovaskuler. ${ }^{1}$

Angka kejadian penyakit kardiovaskular di Indonesia cenderung meningkat terlihat dari hasil Survei Kesehatan Rumah Tangga Nasional (SKRT) dari tahun 1992 - 2002, yang awalnya hanya sebesar $16 \%$ mengalami peningkatan menjadi $26,4 \%$ termasuk Penyakit Jantung Koroner (PJK). Sampai saat ini PJK merupakan penyebab utama kematian, yaitu sekitar $40 \%$ kematian laki-laki usia menengah. Salah satu penyebab terbentuknya aterosklerosis sebagai penyebab PJK yaitu tingginya kadar asam lemak dalam darah. $^{2}$

Minyak goreng yang sering digunakan masyarakat adalah minyak sawit (MS) jenis palm oil. Minyak sawit terutama mengandung unsaturated fatty acid (USFA) 50\% dan saturated fatty acid (SFA) palmitat $44 \%{ }^{3} \quad$ Minyak kelapa sawit banyak mengandung asam lemak jenuh karena mengandung asam palmitat $44 \%$ dan $5 \%$ asam stearat dan diduga menyebabkan kolesterol darah meningkat dan meningkatkan penyakit kardiovaskuler. ${ }^{4}$

Pada penelitian sebelumnya yang menggunakan minyak sawit $50 \%$ terhadap tikus dengan diet tinggi minyak sawit selama 4 minggu, dimana kadar kolesterol lebih rendah dibanding diet standar (kontrol). Kadar trigliserida pada diet tinggi minyak sawit lebih tinggi dibanding diet standar. ${ }^{5}$

Hasil berbeda didapatkan dengan menggunakan minyak sawit $12 \%$ terhadap tikus dengan diet tinggi minyak sawit selama 8 minggu, dimana kadar kolesterol lebih tinggi pada kelompok diet tinggi minyak sawit, tetapi kadar trigliserida lebih rendah namun perbedaanya tidak bermakna. Perbedaan ini mungkin juga disebabkan oleh persentase minyak sawit yang digunakan. ${ }^{6}$

Bawang putih juga dikenal sebagai Allium sativum, mempunyai berbagai macam efek diantaranya adalah efek antioksidan terutama adalah kandungan asam sulfenat yang dibentuk dari dekomposisi dari allicin yang terdapat di dalam bawang putih. Bawang putih dipercaya dapat menyehatkan dan mempunyai aktifitas antioksidan terutama melalui mekanisme penjebakan radikal peroksil. ${ }^{7}$ Selain itu bawang putih juga mempunyai berbagai efek seperti menurunkan kadar kolesterol total dan LDL. ${ }^{8}$

Tujuan penelitian ini adalah melakukan pengujian suplemen bawang putih yang mengandung allicin terhadap tikus dengan diet tinggi minyak sawit dan melihat efeknya terhadap kadar kolesterol dan trigliserida.

\section{METODE}

Jenis penelitian ini adalah eksperimental dengan rancangan penelitian post test only control group design terhadap tiga kelompok tikus putih yang terdiri dari kelompok: 1 . diet standar ad libitum (6-7 gram/hari), 2. diet tinggi minyak sawit dan 3. kelompok perlakuan (diet tinggi minyak sawit + suplemen bawang putih). Tiap kelompok terdiri dari lima ekor tikus putih (Rattus novergicus) jantan Strain Wistar periode 5 januari - 1 Februari 2014. Sampel dari penelitian ini adalah tikus putih yang dipilih secara acak, berumur 2-3 bulan dengan berat badan sekitar 160-250 gram. Kriteria inklusinya yaitu tikus putih jantan galur Wistar (Rattus norvegicus), umur 2-3 bulan, berat badan 155-250 gr. Kriteria eksklusinya adalah sampel dianggap drop out apabila selama penelitian dilaksanakan tikus putih jantan sakit dan mati. Analisis data terhadap perubahan kadar kolesterol dan trigliserida dilakukan melalui uji hipotesis komparatif dan korelatif, yaitu uji One-Way ANOVA.

\section{HASIL}

Penelitian telah dilakukan di laboratorium Hewan FMIPA Jurusan Farmasi Universitas Andalas Padang untuk pemeliharaan hewan percobaan dan labor Biokimia Fakultas Kedokteran Universitas Andalas Padang untuk pemeriksaan kadar kolesterol 
dan trigliserida pada tikus. Hasil yang didapat terlihat pada tabel dibawah ini:

Tabel 1. Berat Badan (gram) Tikus Wistar Sebelum dan Setelah Perlakuan Selama 4 Minggu

\begin{tabular}{cccc}
\hline Kelompok & Waktu & N & Rerata \pm SD \\
\hline 1 & Sebelum & 5 & $199,80 \pm 28,15$ \\
& Setelah & 5 & $259,60 \pm 25,38$ \\
2 & Sebelum & 5 & $190,40 \pm 18,22$ \\
& Setelah & 5 & $239,80 \pm 30,26$ \\
& Sebelum & 5 & $181,40 \pm 12,25$ \\
& & & \\
& Setelah & 5 & $230,80 \pm 28,78$
\end{tabular}

Tabel 1 dan 2 memperlihatkan bahwa setelah uji normalitas Shapiro-Wilk yang menunjukkan distribusi data normal ( $p>0.05$ ) untuk pertambahan berat badan kedua kelompok, kemudian dilakukan One-Way Anova dan didapatkan rerata pertambahan berat badan kelompok tikus tidak bermakna secara statistik ( $p>0.05)$.

Tabel 2. Perbedaan Rerata Pertambahan Berat Badan Tikus Putih (gram)

\begin{tabular}{ccc}
\hline Kelompok & Rerata \pm SD & p \\
\hline 1 & $59,80 \pm 7,49$ & \\
2 & $49,40 \pm 14,34$ & 0,425 \\
3 & $49,40 \pm 18,06$ & \\
\hline
\end{tabular}

Tabel 3 memperlihatkan rerata kadar kolesterol pada kelompok 1 adalah yang paling rendah daripada kelompok 2 dan kelompok 3 .

Tabel 3. Nilai rerata kadar kolesterol (mg/dl)

\begin{tabular}{ccr}
\hline Kelompok & N & \multicolumn{1}{c}{ Rerata \pm SD } \\
\hline 1 & 5 & $90,74 \pm 4,08$ \\
2 & 5 & $109,18 \pm 2,76$ \\
3 & 5 & $107,27 \pm 3,09$ \\
\hline
\end{tabular}

Syarat uji statistik parametrik dengan one way Anova ialah sebaran data harus normal dan varian data harus sama. Untuk mengetahui apakah distribusi data normal maka dilakukan uji Shapiro-Wilk pada hasil pengukuran Kolesterol ketiga kelompok tikus karena jumlah sampel yang kecil $(\leq 50)$. Dari uji Shapiro-Wilk didapat nilai Significancy (p) untuk masing-masing kelompok semuanya $>0,05$. Karena nilai $p>0,05$, maka dapat diambil kesimpulan bahwa distribusi ketiga kelompok data adalah normal.

Untuk mengetahui apakah varians datanya sama maka dilakukan uji homogenitas varian pada hasil pengukuran kolesterol ketiga kelompok tikus. Berdasarkan uji tersebut, maka nilai significancy didapatkan $p=0,805 \quad(p>0,05)$. Dapat diambil kesimpulan bahwa tidak ada perbedaan varians antara kelompok data yang dibandingkan atau varians data sama.

Hasil uji One-Way ANOVA menunjukkan terdapat perbedaan bermakna kadar kolesterol di dalam kelompok, dengan $p=0,000(p<0,05)$.

Analisis post-hoc memperlihatkan bahwa pada kelompok 1 dengan kelompok 2 terdapat perbedaan bermakna $(p=0,000)$. Nilai $p$ antara kelompok 2 dengan kelompok 3 memiliki nilai $p=0,388$ $(p>0,05)$ terdapat perbedaan namun tidak bermakna. Perbedaan bermakna juga terdapat antara kelompok 1 dengan kelompok $3(p=0,000)$.

Tabel 4. Nilai Rerata Kadar Trigliserida (mg/dl).

\begin{tabular}{ccc}
\hline Kelompok & N & Rerata \pm SD \\
\hline 1 & 5 & $75,61 \pm 4,63$ \\
2 & 5 & $84,50 \pm 4,27$ \\
3 & 5 & $83,86 \pm 6,02$ \\
\hline
\end{tabular}

Rerata kadar trigliserida pada kelompok 1 adalah yang paling rendah daripada kelompok 2 dan kelompok 3.

Dari uji Shapiro-Wilk didapat nilai Significancy (p) untuk masing-masing kelompok semuanya $>0,05$. Karena nilai $p>0,05$, maka dapat diambil kesimpulan bahwa distribusi ketiga kelompok data adalah normal.

Untuk mengetahui apakah varians datanya sama maka dilakukan uji homogenitas varian pada hasil pengukuran trigliserida ketiga kelompok tikus. Berdasarkan uji tersebut, maka nilai significancy didapatkan $\mathrm{p}=0,656 \quad(\mathrm{p}>0,05)$. Dapat diambil kesimpulan bahwa tidak ada perbedaan varians antara kelompok data yang dibandingkan atau varians data 
sama. Hasil uji One-Way ANOVA menunjukkan terdapat perbedaan bermakna kadar trigliserida di dalam kelompok, dengan $p=0,029(p<0,05)$.

Analisis post-hoc memperlihatkan bahwa pada kelompok 1 dengan kelompok 2 terdapat perbedaan bermakna $(p=0,016)$ sehingga kadar trigliserida antara kelompok 1 dengan kelompok 2 terdapat perbedaan yang bermakna. Pada kelompok 2 dengan kelompok 3 terdapat perbedaan namun tidak bermakna $(p=0,842)$. Perbedaan bermakna juga terdapat antara kelompok 1 dengan kelompok $3(p=0,024)$.

\section{PEMBAHASAN}

Berdasarkan hasil pada tabel 3 tentang efek suplemen bawang putih terhadap kadar kolesterol tikus yang diberi diet tinggi minyak sawit didapatkan rerata kadar kolesterol kelompok $1=90,74 \mathrm{mg} / \mathrm{dl}$ sedangkan kelompok $2=109,18 \mathrm{mg} / \mathrm{dl}$. Berdasarkan data tersebut, terjadi peningkatan kadar kolesterol pada kelompok 2 yang diberi diet tinggi minyak sawit dibanding kadar kolesterol kelompok 1.

Hal ini terjadi karena minyak sawit merupakan sumber asam palmitat (SFA) dan asam oleat (MUFA) dengan komposisi yang hampir sama. Kadar kolesterol pada kelompok 2 lebih tinggi disebabkan asam palmitat (SFA) meningkatkan kadar kolesterol dengan menurunkan aktifitas reseptor LDL yang berhubungan dengan katabolisme serta meningkatkan formasi kolesterol LDL plasma dengan menurunkan efek turn over kolesterol LDL. ${ }^{9}$ Tikus memiliki kadar kolesterol normal dengan nilai 10-54 mg/dl. ${ }^{10}$

Hasil yang didapat pada penelitian ini berbeda dengan hasil penelitian yang menggunakan tikus wistar diberi diet minyak sawit $12 \%$ selama 60 hari menunjukkan terdapat perbedaan yang bermakna. Hasil penelitiannya yang menunjukkan bahwa nilai rerata berat badan tikus meningkat dengan asupan energi diet $(p<0,05)$. Tingkat serum kolesterol, dan HDL-C yang meningkat secara signifikan $(p<0,05)$, sedangkan tingkat trigliserida dan LDL-C yang menurun tetapi secara statistik tidak signifikan. ${ }^{6}$

Pada uji analisis, penurunan kadar kolesterol antara kelompok 2 dengan kelompok 3 tidak menunjukkan perbedaan yang bermakna dengan nilai $p>0,05$. Hal ini menunjukkan bahwa efek suplemen bawang putih memberikan efek menurunkan kadar kolesterol namun tidak bermakna pada keadaan diet tinggi minyak sawit. Hal ini terjadi karena suplemen bawang putih dapat menghambat reaksi enzim HMGKoA reduktase menyebabkan terjadinnya penurunan sintesa kolesterol dan meningkatkan jumlah reseptor LDL. $^{11}$

Penelitian lain yang menggunakan ekstrak bawang putih terhadap kadar kolesterol pada tikus yang hiperkolesterolemia yang dilakukan selama 6 minggu didapatkan hasil yang signifikan dengan nilai $p$ $=0,002 \quad(p<0,05)$. Pada kelompok perlakuan penurunan kadar kolesterol darah tikus putih sebesar $13,34 \mathrm{mg} / \mathrm{dL}$. Jadi dosis serta lamanya waktu penelitian dapat mempengaruhi kadar dari kolesterol pada tikus. ${ }^{12}$

Berdasarkan hasil pada tabel 4 tentang efek suplemen bawang putih terhadap kadar trigliserida tikus yang diberi diet tinggi minyak sawit didapatkan rerata kadar trigliserida kelompok $1=75,61 \mathrm{mg} / \mathrm{dl}$ sedangkan kelompok $2=84,50 \mathrm{mg} / \mathrm{dl}$. Berdasarkan data tersebut, terjadi peningkatan kadar trigliserida pada kelompok 2 yang diberi diet tinggi minyak sawit dibanding kadar trigliserida kelompok 1.

Hal ini terjadi karena pemakaian kadar minyak sawit yang mencapai 50\% menyebabkan hipertrigliseridemia. Kadar trigliserida mengalami peningkatan diakibatkan oleh pemberian bahan pakan yang mengandung asam lemak jenuh tinggi. ${ }^{13}$ Batas normal kadar trigliserida darah tikus adalah 26-145 $\mathrm{mg} / \mathrm{dl}^{14}$

Kandungan trigliserida dalam lipoprotein yang paling tinggi terdapat pada VLDL $(54,8 \%)$, diikuti LDL (18,7\%), HDL (14,3\%) dan IDL (6,6\%). Peningkatan kadar trigliserida akibat konsumsi lemak jenuh yang tinggi akan menyebabkan peningkatan kadar VLDL. ${ }^{15}$

Hasil uji one way Anova menunjukkan terdapat perbedaaan yang bermakna $(p<0,05)$ pada kadar trigliserida pada penelitian yang dilakukan dengan menggunakan 3 kelompok yaitu kelompok 1 diberi diet standar 6-7gr/hari sesuai kebutuhan selama 4 minggu. Kelompok yang diberi diet tinggi minyak sawit $50 \%$ diberikan ad libitum selama 4 minggu sebagai perlakuan. ${ }^{5}$ 
Dari berbagai penelitian tersebut, diketahui pemberian ekstrak umbi bawang putih dengan kandungan $10 \mathrm{mg}$ alliin (2) dan/atau $4000 \mu \mathrm{g}$ allicin (3) dapat menurunkan kadar trigliserida sebesar $15 \% .^{16}$

\section{KESIMPULAN}

Terdapat perbedaan kadar kolesterol antara kelompok diet standar ad libitum dengan kelompok diet tinggi minyak sawit maupun diet tinggi minyak sawit + suplemen bawang putih yang bermakna secara statistik.

Terdapat perbedaan kadar trigliserida antara kelompok diet standar ad libitum dengan kelompok diet tinggi minyak sawit maupun kelompok diet tinggi minyak sawit + suplemen bawang putih yang bermakna secara statistik.

\section{UCAPAN TERIMAKASIH}

Ucapan terima kasih kepada dr. Husnil Kadri, M.Kes dan Dessy Arisanty, S.Si, M.Sc yang telah banyak mengorbankan waktu, pikiran, dan tenaga dalam memberikan arahan dan masukan dalam penelitian.

\section{DAFTAR PUSTAKA}

1. Barnes MJ, Lapanowski K, Conley A, Rafols JA, Catherine Jen $\mathrm{KL}$ and Dunbar JC. High fat feeding is associated with increased blood pressure, sympathetic nerve activity and hypothalamic mu opioid receptors. Brain Research Bulletin; 2003.

2. Depkes RI. Profil kesehatan Indonesia. Menuju Indonesia sehat 2010. Jakarta: Departemen Kesehatan RI; 2001.

3. Roduit R, Morin J, Masse F, Segall L, Roche E, Newgard CB, Assimacopoulos JF. Prentki M. Glucose down-regulates the expression of the peroxisome proliferator-activated receptor-alpha gene in the pancreatic beta -Cell. J. Biol. Chem; 2000.

4. Clarke R, Frost C, Collins R, Appleby P, Peto R. Dietary lipids and blood cholesterol: quantitative meta-analysis of metabolic ward studies. 1997; BMJ, 314: 112-7.
5. Sastri S, Kadri H. Pengaruh diet tinggi minyak sawit terhadap sel hepatosit tikus. Jurnal Kesehatan Andalas. 2012; Vol 1, No. 3, 125-8.

6. Karaji-Bani M, Montazeri F, Hashemi M. Effect of palm oil on serum lipid profiles in rats. Pak. J. Nutr. 2006; 5(3): 234-6.

7. Vaidya V, Ingold KU, Pratt DA, 2008. Garlic : source of the ultimate antioxidant-sulfrenic acids. Angew. Chem. Int ed. 2008 (diunduh 20 Oktober 2013). Tersedia dari: URL: HYPERLINK http://www3.interscience.wiley.com/ journal/121541677/abstract?CRETRY=1\&SRETR $\underline{\mathrm{Y}=0}$.

8. Javad K, Vosoughi Amir R, dan Akrami Majid. Effects of anethum graveolens and garlic on lipid profile in hyperlipidemic patients. 2007 (diunduh 22 Oktober 2013). Tersedia dari: URL: HYPERLINK http://www.ncbi.nlm.nih.gov/sites/ entrez?db=pubmed\&uid=17328819\&cmd=showd etailview\&indexed=google.

9. Fernandez ML, Kristy L. Mechanisms by which dietary fatty acids modulate plasma lipids. : The Journal of Nutrition. 2006; 2075-8.

10. Harini M, Okid DA. Blood cholesterol level of hypercholesterolemia rat (rattus norvegicus) after VCO treatment. Journal Bioscience. 2009;1(2): 53-8.

11. Syamsiah IS, Tajudin. Khasiat \& manfaat bawang putih. Jakarta: AgroMedia Pustaka; 2003.

12. Priskila M. Pengaruh pemberian ekstrak bawang putih (allium sativum, linn.) terhadap penurunan rasio antara kolesterol total dengan kolesterol HDL pada tikus putih (rattus norvegicus) yang hiperkolesterolemik (skripsi). Fakultas Kedokteran Universitas Sebelas Maret.2008;50-1

13. Silalahi J, Sanggam D. Asam lemak trans dalam makanan dan pengaruhnya terhadap kesehatan. Jurnal Teknologi dan Industri Pangan. 2002; 8:148.

14. Bresnahan J. Biological and physiological data on laboratory animal. Jurnal 15. Kansas State University; 2004.

15. Stipanuk MH. Biochemical and physiological aspects of human nutrition. Saunders Company. 
2000; 306, 315, 333, 918.

16. Yeh YY, Liu L. Cholestrol-lowering effects of garlic extracts and organosulfur compounds: human and animal studies. Journal of Nutrition. 2001; 131: 989S-993S. 